\title{
ARAŞTIRMA/RESEARCH
}

\section{Otistik çocukların anne-babalarının depresyon ve kaygı düzeyleri}

\author{
Levels of depression and anxiety among parents of autistic children
}

Sunay Firat

Çukurova Üniversitesi, Sağlık Bilimleri Fakültesi, Psikiyatri Hemşireliği Anabilim Dalı, Adana, Turkey

Cukurova Medical Journal 2016;41(3):539-547.

Abstract

Purpose: When a disabled child joins a family as a new member, various problems may be observed in intrafamily relations and the functioning of the family. Many families with autistic children experience anxiety because they do not know how to behave towards their children or how this will affect heir lives. Parents of children with developmental disorders such as autism may start having self-confidence issues.

Material and Methods: This study was conducted with the participation of the parents of 40 autistic children randomly selected from among 100 children who were diagnosed with autism spectrum disorder and attending a special education center.

Results: Participants in the study were parents of 26 male $(65 \%)$ and 14 female $(35 \%)$ autistic children. The average age of the children was $62.9 \pm 16.6$ months. .Mothers had higher levels of depression and anxiety scores. Mothers of autistic children who participated in the study received higher scores on depression, state anxiety and trait anxiety compared to fathers. Among mothers, a significan relationship was found between level of education and level of state anxiety.

Conclusion: The findings of this study show that mothers have higher levels of depression and anxiety compared to fathers. This finding might be explained with reference to customs and traditions of the Turkish society in which the study was conducted, which require women to take more responsiblity for family matters. It is recommended that special education and rehabilitation centers provide counseling to parents about the effects of having an autistic children on their lives, and advise them on seeking psychological help if necessary.

Key words: Autism, parents, depression, anxiety

\section{GİRİŞ}

Toplumun en küçük sistemi ailedir. Aile çocuğun gelişiminde ve eğitiminde en etkili rolü olan
Öz

Amaç: Aileye katılan birey özürlü bir çocuk olduğunda aile içi iliş̧kiler ve aile fonksiyonunda bazı sorunlar ortaya çıabilmektedir. Otistik çocuğu olan birçok aile çocuklarına karşı neler yapacaklarını ya da çocuğun kendi yaşantılarını ne yönde etkileyeceğini bilmemenin endișesini taşırlar. Genellikle çok özel gereksinimleri olan bu çocukların aile yaşantısına uyumunun sağlanabilmesinde bazı sıkıntılar yaşanmaktadır. Otizm gibi gelişimsel bozukluğu olan çocuğa sahip anne babalar zaman zaman kendilerine olan güvenlerini yitirdiklerini hisseder.

Gereç ve Yöntem: Araştırma bir özel eğitim merkezine devam eden 100 otizm spektrum bozukluğu tanısı almış ve eğitimlerine devam eden çocuklardan tesadüfi olarak seçilen 40 otistik çocuğun annesi ve babast ile yapılmıştır.

Bulgular: Çalışmamıza 26’sı (\%65) erkek, 14’ü (\%35) kız toplam 40 otistik çocuğun anne ve babası katılmıştır. Çocukların yaş ortalaması $62.9 \pm 16.6$ ay olarak saptanmıştır. .Otistik çocukların annelerinde babalara göre depresyon ve kayg1 puanları daha yüksekti. Otistik çocukların annelerinin eğitim düzeyleri ile durumluk kaygı düzeyleri arasında anlamlı bir fark bulunmuştur.

Sonuç: $\mathrm{Bu}$ araştırmanın sonuçlarına göre, annelerde depresyon, anksiyete, babalara göre daha yüksek bulunmuştur. Bulunan bu sonucun, araştırmanın yapıldığı toplumun ve Türk toplumunun gelenek ve göreneklerine göre aile içinde annenin aldığı sorumlulukların daha fazla olmasından kaynaklandığı düşünülebilir. Özel eğitim ve rehabilitasyon merkezlerinde anne ve babalara, otistik çocuğa sahip olmanın yaşamlarında olabilecek etkileri aktarılmalı ve gerektiğinde ruhsal destek almaları sağlanmalıdır.

Anahtar kelimeler: Otizm, anne, baba, depresyon, kayg1

çevrelerden biridir. Özellikle, yaşamla ilgili bazı davranış kalıpları, sosyal etkileşimlerle ilgili bazı kural ve roller, temel alışkanlıklar günlük ilişkiler sırasında öğrenildiğine göre; aile, çocuk için bütün bu 
becerilerin temelinin atıldığ1 yer olarak önem taşımaktadır ${ }^{1,2}$.

Normal ya da özürlü olsun her çocuğun içinde büyüyüp gelişebileceği, bazı kural ve rolleri yaşayarak öğrenebileceği aile çevresi içinde bulunma gereksinimi vardır ${ }^{3}$. Ancak, aile yaşamının sağlıklı bir şekilde sürdürülmesini engelleyen sorunlar çıkabilmektedir. Aile üyelerinin huzursuzluğuna yol açan engellemeler, ailenin varlığını korumasını güçleştirmekte, aile üyelerinin ruhsal ve sosyal sağlıklarını bozmaktadır. Bu durum sonucu bazen aile, toplumsal sistem içinde hasta bir kurum niteliği kazanabilmektedir. Aile işlevlerini bozan unsurlardan birisi de aileye yeni bir bireyin katılmasıdır. Bir çocuğun engelli olduğunun öğrenilmesi, yetersizliğin derecesi ne olursa olsun ailesi için yüksek derecede stres verici bir olaydır ${ }^{4}$ ve herhangi bir anormal durumun olması ailede hayal kırıklığ1 yaratmaktadır ${ }^{5}$.

Anne/baba, alışılması zor olan bu durum karşısında stres yaşamakla birlikte, günlük hayatın gereklerini yerine getirmede zorlanmakta, başta evlilik, duygusal ilişkiler olmak üzere kişilerarası ilişkilerinde de gergin olabilmektedirler. Yaşanan bu travmatik duruma uygun olmayan tepkiler ve ailenin içine düştüğü suçluluk duygusu anne-babayı depresyona götürmekte, aynı zamanda çocuğun bakımı için gerekli olan fazla zaman, para, enerji gereksinimi anne/babanın stres yaşamasına neden olmaktadır ${ }^{6}$.

Otizm en geniş anlamıyla, yaşamın erken dönemlerinde başlayan ve yaşam boyu süren, sosyal ilişkiler, iletişim, davranış ve bilişsel gelişmede gecikme ve sapmayla belirli nöropsikiyatrik bir bozukluktur ${ }^{7,8}$.

Son yıllarda yapılan çalışmalar otizmde genetik faktörlerin etkili olduğu yönündedir. Ancak nedenleri konusunda hala belirsizlik ve karmaşıklık devam etmektedir'. Bristol (1984), otizmi diğer gelişim bozukluklarıla kıyasladığında, bazı faktörlerin (belirsizlik, şiddeti ve süresi, toplumlardaki örneklerle uyușma azlığı) bu ailelerde uyumu zorlaştırdığını belirtmiştir. Ayrıca otizmli çocuğun genellikle fiziksel olarak normal göründüğünü, engelinin derecesinin belirsiz olduğunu ve bunun $\mathrm{da}$ ailenin yetenek ve potansiyellerle ilgili gerçekçi beklentiler geliştirmesini zorlaştırdığını vurgulamıştı1 ${ }^{10}$.

Otistik çocukların, diğer çocuklar gibi anne/babaları ile iletişime geçmediği, başkaları ile göz kontağı kurmadığ1, birçoğunun konuşmadiğ1 ve stereotipilerinin olduğu, rutinlerinin bozulmasına aşırı tepki gösterdikleri dikkat çekmiş ve bu nedenlerden dolayı ailelerin otizmli çocuklarına uyum sağlamalarının ve bu durumla baş etmelerinin diğer engel gruplarına göre daha güç olduğunu belirtmişlerdir ${ }^{11,12}$

Otizm gibi gelişimsel bozukluğu olan çocuğa sahip ailelerden bazıları zaman zaman kendilerine olan güvenlerini yitirdiklerini hissetmektedirler. Çünkü hiçbir otistik çocuk, otistik özellikleri yönünden birbirinin aynısı değildir. Anne-babalar tanımlanması oldukça güç olan bir seri problem davranış ile karşı karşıya kalmaktadırlar ${ }^{3}$. İletişim kuramayan bir çocuğun gereksinimleri ve istekleri ile ilgilenme, aile ortamında düzeni devam ettirmeye çalışma, tuhaf ve alışılmamış davranışlarla baş etme, tehlikeleri tanımayan çocuğu sürekli olarak denetleme ve bu arada kişisel gereksinimleri ve ailenin diğer fertlerinin gereksinimlerini gidermeye çalışma, yeterince yorucu ve stres vericidir ${ }^{2}$. İletişim kurmadaki güçlük ve anlama özürlü olmaları, onlara sevgiyle yaklaşan aile bireylerinde duygusal sorunlar ortaya çıkarmaktadır. Aile panik yaşamakta, suçluluk duymakta, acı çekmekte ve bunlara bağlı olarak, rollerini yerine getirmekte zorlanmaktadırlar ${ }^{12,13,14,15}$.

Gündoğdu (1995) ${ }^{16}$ yaptığ1 çalışmada, otistik ve normal çocuğa sahip anne-babaların evlilik uyumlarını algılamalarını ve durumluluk-sürekli kayg1 ve depresyon bakımından karşılaştırılmışlardır. 40 çiftin katıldığı bu araştırmada, otistik çocuğa sahip anneler, Birtchnell Eş Değerlendirme Ölçeği'nin yalnızca "güvenilebilirlik" alt boyutunda, normal çocuğa sahip annelere göre daha yüksek puan almışlardır. Otistik çocuğa sahip babalar, Birtchnell Eş Değerlendirme Ölçeği'nin yalnızca "kopukluk" alt boyutunda normal çocuğa sahip babalara göre daha düşük puan almışlardır. $\mathrm{Bu}$ ölçeğin "güvenilebilirlik" ve "kopukluk" alt boyutundaki sonuçları dikkate alındığında, otistik çocukların anne ve babalarının evlilik uyumuna ilişkin algılarının, normal çocuğa sahip anne ve babalara göre daha olumlu olduğu gözlenmiştir.

Ülkemizde otistik çocukların aileleriyle ilgili yapılan çalş̧malarda hep annelerin ruhsal durumları değerlendirilmiş ve başka engelli gruplarının anneleri ile karşılaştırılmıştır ${ }^{17}$. Ancak otistik çocukların eğitim ve rehabilitasyonlarına anne/babanın birlikte dahil edilmesi çok önemlidir. Çünkü anne/babaların çocuklarının tedavi ve eğitimi sırasında profesyonellerden ruhsal ve eğitimsel destek almaları ve birbirleriyle yardımlaşmaları bu zorlu süreçte büyük önem taşımaktadır. 
Çalışmamızın sonuçlarına göre anne-babalara hem ruhsal destek, hem de çocuklarına eğitim ve rehabilitasyon sürecinde bilgi verici danışmanlık gibi destek programları geliştirilecektir.

Otizm tanısı almış çocukların anne-babalarının ruhsal durumları (kayg1 ve depresyon düzeylerinin yüksek olması) çocuklarının eğitim ve rehabilitasyonuna katkısını olumsuz yönde etkilemektedir. Oysa ki, bu çocukların eğitim ve rehabilitasyonuna ailelerin katılımı tedavide çok önemlidir. Çünkü Türkiye'de otistik çocuklar, tam teşekküllü hastanelerin çıkardıkları sağlık raporları ile eğitim ve rehabilitasyon merkezlerine ayda, seansı 45'er dakikadan 8 kez (haftada 2 kez) bireysel eğitime gitmektedirler. Bu eğitim ise yeterli değildir. $\mathrm{Bu}$ yüzden anne/babaların çocuklarının eğitimine nasıl katkıda bulunacaklarını bilmeleri çok önemlidir.

Bu çalışma, otistik çocuğa sahip ailelerin yaşadıkları sorunlar ile ruhsal durumlarını belirlemek amaciyla planlanmıştır. Bu amaçla, otistik çocuğu olan anne ve babaların yaşadıkları anksiyete ve depresyon düzeyleri incelenmiş ve sonuçları değerlendirilmiştir.

\section{GEREÇ VE YÖNTEM}

Araştırmamız, bir özel eğitim ve rehabilitasyon merkezine devam eden 100 otizm spektrum bozukluğu tanısı almış ve eğitimlerine devam eden çocuklardan tesadüfi olarak seçilen herhangi bir sağlık kuruluşunun Çocuk ve Ergen Sağlığı ve Hastalıkları polikliniklerinden otizm spektrum tanısı almış 40 çocuğun annesi ve babası ile yapılmıştır. Veriler, araştırmacı tarafindan hazırlanan Bilgi Formu ile Beck Depresyon Ölçeği (BDÖ) ve Durumluk-Sürekli Kayg1 Envanteri kullanılarak toplanmıştır.

\section{Veri toplama araçları}

Veriler, aileyi tanıtıcı bilgi formu ve ailelerle yapılan birebir görüşmelerle toplanmıştır. Araştırmada otistik çocuğa sahip anne babaların sosyodemografik özellikleri (yaş, çalışma durumu, eğitim düzeyi vb.) otistik çocukların cinsiyeti, tanı konulma yaşı gibi bazı özellikleri ve ailelerin ruhsal durumları ile yaşadıkları sorunlar değerlendirilmiştir.

Anne-babaların otistik çocuğa sahip olmaktan dolayı yaşadıkları sorunlar, hissettikleri, çevreyle olan ilişkileri, yaşam şekillerinin nasıl değiştiği, geleceğe yönelik endişeleri ve yaşama bakış açılarında ne gibi değişikler olduğu araştırılmıştır.
Bütün anne-babalara araștırmacı tarafindan hazırlanmış sosyo-demografik bilgi formu, Beck Depresyon Ölçeği ve Durumluk-Sürekli Kayg1 Ölçeği uygulanmıştır ve ölçekler puanlanmıştır.

\section{Durumluk-Sürekli Kayg1 Ölçeği (DSKÖ)}

Spielberger ve arkadaşları tarafından geliştirilen bu ölçek, her biri 20 sorudan oluşan sürekli ve durumluk olmak üzere iki alt ölçekten oluşmaktadır. Durumluk kayg1 ölçeği, bireyin belirli bir anda ve belirli koşullarda kendini nasıl hissettiğini, sürekli kayg1 ölçeği ise bireyin içinde bulunduğu durum ve koşullardan bağımsız olarak kendini nasıl hissettiğini belirler. İki alt ölçekten de elde edilen toplam puan değeri 20-80 arasında değişir. Değerlendirilme yapilırken her madde için maddenin pozitif ya da negatif özelliğine göre 1 (ya da -1) ile 4 (ya da -4) arasinda bir puan verilmekte olup elde edilecek toplam puana 50 eklenmektedir. Toplam kayg1 puanı ne kadar yüksekse, ölçeği dolduran kişinin kayg1 düzeyinin de fazla olduğu değerlendirilir. Yüksek puan yüksek kayg1 düzeyini, düşük puan ise düşük kayg1 düzeyini gösterir. Ölçeğin Türkçeye uyarlanması, geçerlilik ve güvenilirlik çalışması Öner ve Le Compte ${ }^{18}$ tarafindan yapılmıştır. Ölçeklerde doğru ve tersine dönmüş ifadeler bulunmaktadır. Doğrudan ifadelerden elde edilen puandan tersine dönmüş ifadelerden elde edilen puan çıarıllip bulunan sayıya durumluk kaygı ölçeği için 50 , sürekli kayg1 ölçeği için 35 eklenir. Her iki ölçekten elde edilen puanlar kuramsal olarak 20-80 arasında değişir

\section{Beck Depresyon Ölçeği (BDÖ)}

Denekte depresyon yönünden riski belirlemek ve depresif belirtilerin düzeyini belirlemek amaciyla Beck tarafindan geliştirilen 4'lü likert tipi kendini değerlendirme ölçeğidir. Formun Türkçe geçerlilik ve güvenilirliği Hisli (1989) ${ }^{19}$ tarafindan yapılmış olup, ölçeğin Cronbach alfa katsayısı 0.80 olarak bulunmuştur. Ölçeğin Türkçe geçerlik ve güvenirlik makalesinde kesme puanının 17 olarak kabul edildiği belirtilmiştir. Ölçekten alınacak toplam puan 0-63 arasında değișmektedir ${ }^{18}$. Anne ve babaların depresyon düzeyi, BDÖ ile ölçüldü. BDÖ, çalışma grubumuzdaki aynı soyadlı anne ve babaya eş zamanlı olarak uygulanmıştır. Anne, baba ve uygulayıcı aynı odada bulunmuşlardır. Anne ve babanın soruları kendi başlarına, yaşadıkları son 1 haftayı gözönüne alarak cevaplamaları istenmiştir. Soruları olması halinde araştırmacıya sorabilecekleri hatırlatılmıştır. Cevapladıkları sorulardan aldıkları 
puana göre toplam skorları belirlenmiştir. Skorların yorumlanması şu şekilde olmuştur ${ }^{21}$ : 0-11 puan: depresyon yok; 12-17 puan: hafif depresyon; 18-29 puan: orta şiddetli depresyon; 30-63 puan: şiddetli depresyon. Araştırma için yerel etik kurul onayı alınmış, katılımcılar aydınlatılmış onam vermişlerdir..

\section{İstatistiksel analiz}

Verilerin istatistiksel analizinde IBM SPSS Statistics Versiyon 20.0 paket programı kullanıld1. Kategorik ölçümler sayı ve yüzde olarak, sayısal ölçümlerse ortalama ve standart sapma (gerekli yerlerde ortanca ve minimum - maksimum) olarak özetlendi. Kategorik ölçümlerin gruplar arasında karşılaştırılmasında Ki Kare test istatistiği kullanıldı. Sayısal ölçümlerin normal dağılım varsayımını sağlayıp sağlamadığ1 Kolmogrov Smirnov testi ile test edildi.

Gruplar arasında sayısal ölçümlerin karşılaştırılmasında varsayımların sağlanması durumunda Bağımsız gruplarda $\mathrm{T}$ testi, varsayımların sağlanmaması durumunda ise Mann Whitney U testi kullanıldı. Bağımlı sayısal ölçümlerin karşılaştırılmasında Bağımlı Gruplarda $T$ testi kullanıldı. Normal dağılım göstermeyen sayısal ölçümleri ikiden fazla grup arasinda genel karşılaştırmada Kruskal Wallis testi kullanıldı. Sayısal ölçümler arasındaki etkileşimi incelemede varsayımların sağlanması durumunda Pearson korelasyonu, varsayımların sağlanmamas1 durumunda ise Spearman korelasyonu kullanildı. Tüm testlerde istatistiksel önem düzeyi 0.05 olarak alındi.

\section{BULGULAR}

Çalıșmamıza 26's1 (\%65) erkek, 14'ü (\%35) k1z toplam 40 otistik çocuğun anne ve babası katılmıştır. Çocukların yaş ortalaması $6.9 \pm 16.6$ aydı. Otistik çocukların annelerinin yaş ortalaması $35.25 \pm 4.65$ iken babalarının yaş ortalaması $40.8 \pm 5.3$ idi.Tablo 2'ye göre, otistik çocukların annelerinin 16's1 (\%38.4) ilköğretim mezunu, 14'ü (\%33.6) lise ve 10'unun (\%24) ise üniversite mezunu olduğu saptanmıştır. Çalışma durumu değerlendiğinde $30(\% 75)$ annenin çalışmadığ1 ve ev hanımı olduğu, 10 (\%25) annenin çalıştığ 1 tespit edilmiştir.

Tablo 1. Otistik çocukların sosyo-demografik özellikleri

\begin{tabular}{|l|l|l|}
\hline Değişkenler & Kız & Say1 (\%) \\
\hline \multirow{3}{*}{ Cinsiyet } & Erkek & $14(35)$ \\
\hline \multirow{4}{*}{ Yaş (Ay) } & $0-59$ & $26(65)$ \\
\cline { 2 - 3 } & $60-83$ & $20(50)$ \\
\cline { 2 - 3 } & 84 ve üzeri & $15(40)$ \\
\hline \multirow{3}{*}{ Tanı } & YGB & $5(10)$ \\
\cline { 2 - 3 } & AYGB & $28(70)$ \\
\hline \multirow{4}{*}{ Ĕ̈itim } & Özel Ĕ̈itim (ÖE) & $12(30)$ \\
\cline { 2 - 3 } & Kreş/Anaokulu & $15(37.5)$ \\
\cline { 2 - 3 } & ÖE+Kreş/Anaokulu & $2(5)$ \\
\cline { 2 - 3 } & İlköğretim Okulu (Kaynaştırma) & $20(50)$ \\
\hline
\end{tabular}

YGB: Yaygın gelişimsel bozukluk; AYGB: atipik yaygın gelişimsel bozukluk

Tablo 2. Otistik çocukların annelerin sosyo-demografik özellikleri

\begin{tabular}{|l|l|l|}
\hline Değişkenler & $20-30$ & Anne Say1 (\%) \\
\cline { 2 - 3 } Yaş & $31-40$ & $6(15)$ \\
\cline { 2 - 3 } & 41 ve üzeri & $30(75)$ \\
\hline \multirow{3}{*}{ Ë̆itim } & Illköğretim & $4(10)$ \\
\cline { 2 - 3 } & Lise & $16(38.4)$ \\
\cline { 2 - 3 } & Üniversite & $14(33.6)$ \\
\hline \multirow{3}{*}{ Çalısma } & Ev Hanımı & $30(24)$ \\
\cline { 2 - 3 } & Çalışıor & $10(25)$ \\
\hline
\end{tabular}


Tablo 3. Otistik çocukların babalarının sosyo-demografik özellikleri

\begin{tabular}{|l|l|c|}
\hline \multicolumn{2}{|l|}{ Değişkenler } & Baba Say1 (\%) \\
\hline \multirow{4}{*}{ Yaş } & $30-40$ & $21(52.5)$ \\
\cline { 2 - 3 } & $41-50$ & $18(45)$ \\
\cline { 2 - 3 } & 51 ve üzeri & $1(2.5)$ \\
\hline \multirow{4}{*}{ Ĕ̈itim } & İlköğretim & $9(22.5)$ \\
\cline { 2 - 3 } & Lise & $19(47.5)$ \\
\cline { 2 - 3 } & Üniversite & $12(30)$ \\
\hline \multirow{3}{*}{ Meslek } & İşçi & $9(22.5)$ \\
\cline { 2 - 3 } & Memur & $19(47.5)$ \\
\cline { 2 - 3 } & Esnaf/Tüccar & $8(20)$ \\
\cline { 2 - 3 } & Serbest (Avukat, Doktor vs.) & $4(10)$ \\
\hline
\end{tabular}

Tablo 3'e göre, otistik çocukların babalarının 9'u $(\% 22,5)$ ilköğretim mezunu, 19'u $(\% 47,5)$ lise ve 12 'sinin (\%30) ise üniversite mezunu olduğu saptanmıştır. Otistik çocukların babalarının meslekleri değerlendirildiğinde 19'unun $(\% 47,5)$ memur, 9'unun (\%22,5) işçi, 8'inin (\%20) esnaf/tüccar olduğu saptanmıştır. Otistik çocukların yaşları ile anne babaların Depresyon (BECK), Durumluk (STAI-I) ve Sürekli (STAI-II) kaygı ölçek puanları arasında anlamlı bir fark bulunmamıştır
( $\mathrm{p} \geq 0.05)$. Otistik çocukların annelerinin depresyon puan1 16.9 \pm 6.9 , durumluk kayg1 puanı 35.8 \pm 10.33 , sürekli kayg1 puanı 45.6 $\pm 7,79$; babalarının depresyon puanı 13.2 \pm 6.6 , durumluk kayg1 puanı 31.4 \pm 5.6 , sürekli kayg1 puanı $38.2 \pm 5$ idi. Analizler sonucunda annelerin depresyon ve kaygı puanları daha yüksekti. Otistik çocukların anne/babalarının yaşları ile Depresyon (BECK), Durumluk (STAI-I) ve Sürekli (STAI-II) kaygı ölçek puanları arasında anlamlı bir fark bulunmamıştır ( $\mathrm{p} \geq 0.05)$.

Tablo 4. Çocukların tanı durumuna göre anne babanın depresyon (BDÖ), durumluk (STAI-I) ve sürekli (STAIII) kaygı düzeyleri puanları

\begin{tabular}{|l|l|l|l|l|l|l|l|}
\hline & \multicolumn{3}{|l|}{ ANNE } & BABA & Max \\
\hline Tanılar & Ölçekler & $\mathbf{N} \pm$ Ss & Min & Max & N \pm Ss & Min & Ma \\
\hline \multirow{3}{*}{ YGB } & BDÖ & $17.5 \pm 6.77$ & 12 & 38 & $13.9 \pm 7.12$ & 5 & 32 \\
\cline { 2 - 8 } & STAI-I & $37.6 \pm 10.6$ & 22 & 63 & $32.2 \pm 5.5$ & 22 & 41 \\
\cline { 2 - 8 } & STAI-II & $46.6 \pm 7.45$ & 32 & 65 & $38.7 \pm 5$ & 30 & 48 \\
\hline \multirow{3}{*}{ AYGB } & BDÖ & $15.4 \pm 7.24$ & 12 & 38 & $11.6 \pm 5.04$ & 7 & 26 \\
\cline { 2 - 8 } & STAI-I & $31.3 \pm 8.42$ & 22 & 54 & $29.4 \pm 5.6$ & 22 & 42 \\
\cline { 2 - 8 } & STAI-II & $43.2 \pm 8.38$ & 26 & 50 & $37.1 \pm 4.9$ & 32 & 45 \\
\hline
\end{tabular}

YGB: Yaygın gelişimsel bozukluk; AYGB: atipik yaygın gelişimsel bozukluk; BDÖ: Beck depresyon ölçeği

Tablo 4'e göre Yaygın Gelişimsel Bozukluk ile Atipik Yaygın Gelişimsel Bozukluk tanılarını almış çocukların anne babalarının Depresyon (BECK), Durumluk (STAI-I) ve Sürekli (STAI-II) Kayg1 düzeyleri puanları karşılaştırıldığında, Yaygın Gelişimsel Bozukluk tanısını almış çocukların anne babalarının ölçek puanları daha yüksek bulunmuştur. Ancak bu ölçek puanları istatistiksel olarak anlamlı bulunmamıştır. Şekil 1.'e göre otistik çocukların anne babalarının depresyon ölçekleri $(p=0.011)$, durumluk kayg1 $(p=0.015)$ ve sürekli kayg1 $(p=0.000)$ puanları karşılaştırıldığında, annelerin depresyon, durumluk ve sürekli kaygı puanları babaların aldıkları puanlardan daha yüksek bulunmuştur. $(\mathrm{p} \leq 0.05)$.
Şekil 2'ye göre otistik çocukların annelerinin eğitim düzeyleri ile durumluk kayg1 düzeyleri arasinda anlamlı bir fark bulunmuştur $(\mathrm{p}=0.031)$. Annelerin eğitimleri yükseldikçe durumluk $(\mathrm{p}=0.031)$ kayg1 düzeylerinin düştüğü saptanmıştır. $(\mathrm{p} \leq 0.05)$.

Otistik çocukların babalarının eğitim düzeyleri ile depresyon ve kayg1 ölçek puanları karşılaştırıldığından aralarında anlamlı bir fark bulunamamıştır ( $\geq \geq 0.05)$. Şekil 3'ye göre otistik çocukların annelerinin çalışma durumu karşılaştırıldığında, ev hanımı çalışmayan annelerin durumluk $(p=0.072)$ ve sürekli $(p=0.031)$ kayg1 düzeyleri çalışan annelerden daha yüksek bulunmuştur. ( $\mathrm{p} \leq 0.05)$. 


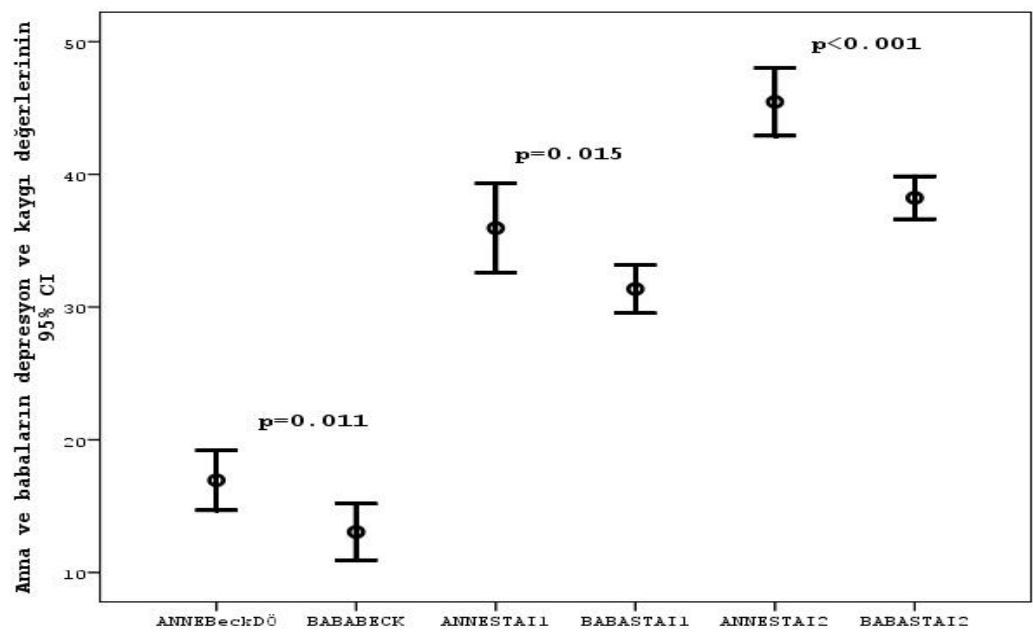

Şekil 1. Otistik çocukların anne babalarının Beck depresyon ölçeği (BDÖ), durumluk (STAI-) ve sürekli (STAI-II) kayg1 ölçek puanları arasındaki ilişki

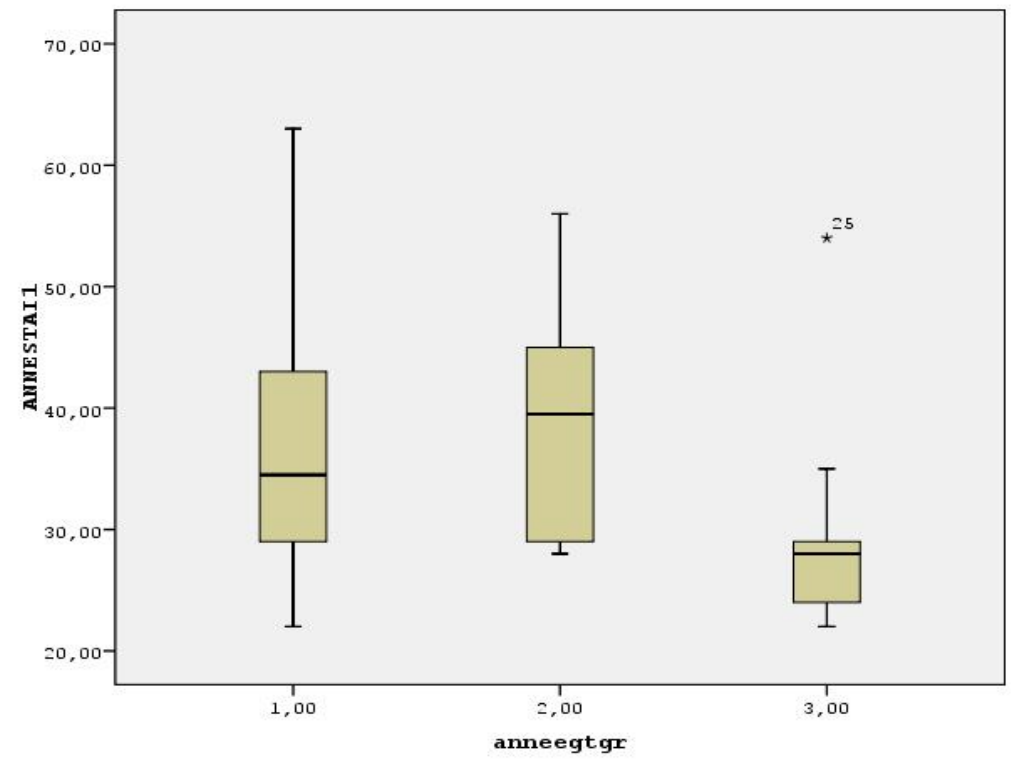

Şekil 2. Otistik çocukların annelerinin eğitim durumları ile Beck depresyon ölçeği (BDÖ), durumluk (STAI-I) ve sürekli (STAI-II) kaygı ölçek puanları arasındaki ilişki 


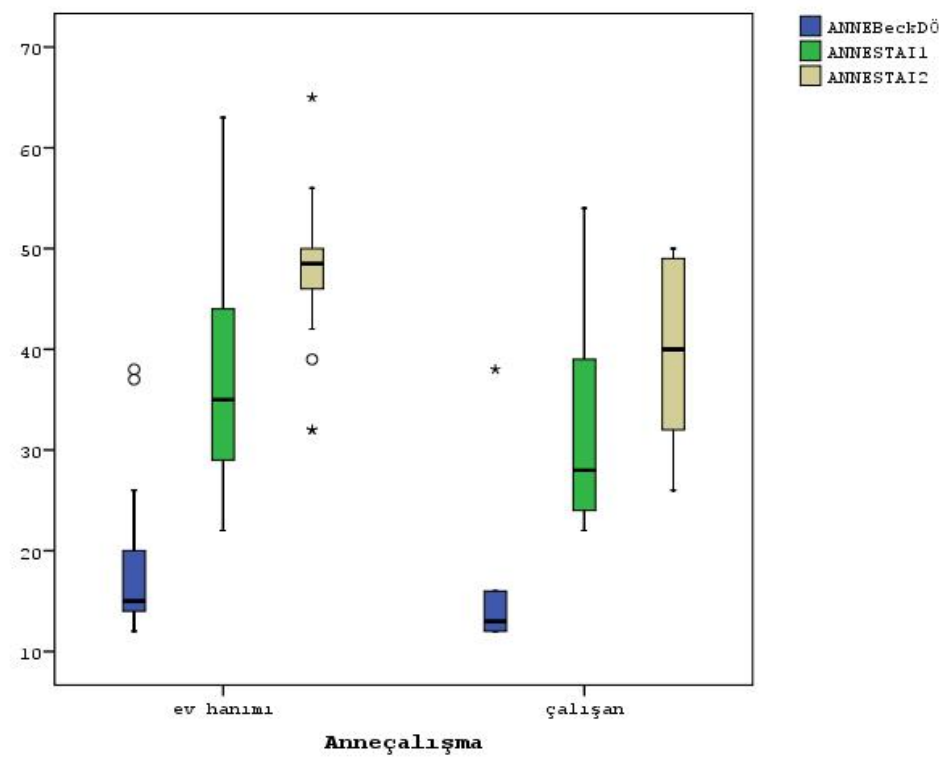

Şekil 3. Otistik çocukların annelerinin eğitim durumları ile Beck depresyon ölçeği (BDÖ), durumluk (STAI-I) ve sürekli (STAI-II) kaygı ölçek puanları arasındaki ilişki

\section{TARTIŞMA}

Özel eğitim ve rehabilitasyon merkezlerinde tedavi ve rehabilite edilen otistik çocukların anne ve babaları, ilk etapta çocuklarının engelini anlamaya, sonrasinda bu duruma uyum sağlamaya çalışmaktadırlar. Anne ve babanın dahil olduğu bu süreçte, çocukların yaşam boyu hep desteğe ihtiyacı olduğundan anne ve babaların yaşantılarının psikolojik, fiziksel ve sosyal alanlardaki iyilik hallerinde iniş ve çıkışlar olmakta ve yaşam kalitesini ilgilendiren parametrelerinde değişimler olmaktadir ${ }^{22}$.

Değerlendirme için kullanılan ölçeklerin ve formların çeşitliliği, depresyon düzeyinin, durumluk ve sürekli kayg1 düzeyleri ve anne babalara ait sosyodemografik özelliklerle olan ilişkisinin de araştırılmasını sağlamıştır. Bu araştırmada amaç özel eğitim ve rehabilitasyon merkezinde tedavi gördüğü ve destek eğitim aldığ1, otizm spektrum bozukluğu tanısı almış çocukların anne ve babalarının depresyon, durumluk ve sürekli kayg1 düzeylerini analiz etmektir. Daha önce buna benzer çalışmalar yapılmış olmasına rağmen hem anne hem de babanın birlikte ele alındığ 1 bir araştırma olması bu araştırmayı farklılaştırmaktadır.
Çalışmamızda otistik çocukların yaşları ile anne babaların Depresyon (BECK), Durumluk (STAI-I) ve Sürekli (STAI-II) kayg1 ölçek puanları arasında anlamlı bir fark bulunmamıştır $(\mathrm{p} \geq 0.05)$. Bu bulgumuz Fırat ve arkadaşlarının ${ }^{17}$ çalışmasıyla uyumlu bulunmasına karşın, yaşı küçük otistik çocuğu olan annelerin depresyon, durumluk ve sürekli kayg1 düzeylerinin daha düşük olduğu bildirilmiştir.

Engelli çocukların annelerinin eğitim düzeyi arttıkça ruhsal belirti gösterme durumunun azaldığı ve eğitim düzeyinin ruhsal belirti gösterme durumunu etkilemediği tespit edilmiştir. Yapılan çalışmalar bu bulguyu desteklemektedir ${ }^{17,23-28}$. Çalışmamız literatürdeki araştırma sonuçları ile uyumlu bulunmuştur. Otistik çocukların anne babalarının eğitim düzeyleri ile depresyon ve kayg1 düzeyleri arasında anlamlı bir fark bulunmamıştır. Sadece otistik çocukların annelerinin eğitim düzeyleri ile durumluk kayg1 düzeyleri arasında anlamlı bir fark bulunmuştur ( $\mathrm{p}=0.031)$. Annelerin eğitim düzeyleri yükseldikçe durumluk $(\mathrm{p}=0.031)$ kayg1 düzeylerinin azaldığı saptanmıştır ${ }^{31}$. Engelli çocukların aileleri ile yapılan çalışmalarda, ailelerin eğitim seviyesi yükseldikçe, anksiyete ve stres düzeylerinin arttığ1 görülmüştür ${ }^{14,15}$ 
Çalışmamızda otistik çocukların anne babalarının depresyon ölçeği $(\mathrm{p}=0.011)$, durumluk kayg1 $(p=0.015)$ ve sürekli kayg1 $(p=0.000)$ ölçek puanları karşılaştırıldığında, annelerin depresyon, durumluk ve sürekli kayg1 puanları babaların aldıkları puanlardan daha yüksek bulunmuştur. ( $\mathrm{p} \leq 0.05)$. Çalışmamızın sonuçları Baykoç ve arkadaşlarının 27 yaptığı çalışma ile uyumlu bulunmuştur.

Heller ve arkadaşlarının 28 özel gereksinimli çocuklarla ilgili yaptıkları araştırmada ise, özel gereksinimli çocuklarda annelerin babalara göre çocuğun davranışlarını şekillendirme ve sağlıklı olma halini devam ettirebilme konusunda etkisinin daha büyük olduğu bulunmuştur. $\mathrm{Bu}$ araştırmanın sonuçlarına göre, annelerde depresyon, anksiyete, babalara göre daha yüksek bulunmuştur. Bulunan bu sonucun, araştırmanın yapıldığı toplumun ve Türk toplumunun gelenek ve göreneklerine göre aile içinde annenin aldığı sorumlulukların daha fazla olmasından kaynaklandığı düşünülebilir. Ancak örnek sayısının daha fazla olmasını beklenilmiş olmasına rağmen sadece 40 çocuğun anne babasının ölçekleri doldurmaya gönüllü olması, ailelerin bu tür ruhsal değerlendirme ölçeklerine karşı daha dirençli olduklarını düşündürebilir. Çünkü ailelerin gözünde, bu tür ölçeklerden çıkacak sonuçların, anne-babalık görevlerinde yetersizliklerini değerlendirme arac1 olarak algılandığını düşündürmektedir.

Örnek sayısının daha fazla olmaması bu çalışmanın sinırlılıklarından biri olarak düşünülebilir. Ayrıca otistik çocuklara kaç yaşında tanı konulduğu, dolayısıyla çocukların aldıkları özel eğitim ve/veya kreş, anaokulu sürelerinin de ebeveynlerin kayg1 ve depresyon düzeylerini etkileyebileceği düşünülmüştür. $\mathrm{Bu}$ durum çalışmamızın sinırlılıklarından biridir. Ancak ebeveynlerin ruh sağlıklarının iyi olması çocuklarının eğitim ve rehabilitasyonuna katılımı eğitim ve tedavi sürecinde çok önemlidir. Çalışmamızda, Türkiye'de otistik çocukların sınırlı sayıda özel eğitim almalarından yola çıkarak anne babaların ruh sağlıklarının nasıl olduğunu ortaya çıkarmak adına çalışmamız gerçekleştirilmiştir.

Sonuç olarak, otistik çocukların eğitim ve bakımını üstlenmenin sadece annenin sorumluluğu olmadığı, bu konuda anne ve babanın ortak sorumluluk alması gerektiği öğretilmelidir. Annelerin psikolojik ve sosyal yönden iyilik hallerinin arttırılması adına çalışma yaşamına dahil edilmesi gerekmektedir. Otistik çocuğa sahip olan anne ve babaların, psikolojik ve fiziksel destek alması gerekmektedir.
Özel eğitim ve rehabilitasyon merkezlerinde anne ve babalara, otistik çocuğa sahip olmanın yaşamlarında olabilecek etkileri aktarılmalıdır. Yalnız olmadıklarını hissettirmek adına, grup ile psikolojik danışma hizmetleri de verilmelidir.

\section{Teşekkür}

$\mathrm{Bu}$ araştırma, Çukurova Üniversitesi, Bilimsel Araştırma Projeler (BAP) Koordinasyon Birimi tarafindan ASYO2013BAP3 proje koduyla desteklenmiştir.

\section{KAYNAKLAR}

1. Görgü Eİ. Üç-yedi yaş arası otistik çocuğa sahip olan annelerin algıladıkları sosyal destek düzeyleri ile depresyon düzeyleri arasındaki ilişki (Yüksek lisans tezi). İstanbul, Marmara Üniversitesi, 2005.

2. Bircan GA. Otistik çocuğa sahip ailelerin aile işlevlerinin incelenmesi (Yüksek lisans tezi). Ankara, Hacettepe Üniversitesi, 2004.

3. Darıca N. Otizm ve Otistik Çocuklar. Özgür Yayınları, İstanbul, 2000.

4. Bilal E, Dağ İ. Eğitilebilir zihinsel engelli olan ve olmayan çocukların annelerinde stresi stresle başa çıkma ve kontrol odağının karşılaştırılması, Çocuk ve Gençlik Ruh Sağlığı Dergisi. 2005;12:56-68.

5. Okanlı A, Ekinci, M, Gözüağca D, Sezgin S. Zihinsel engelli çocuğa sahip ailelerin yaşadıkları psikososyal sorunlar, Uluslararas1 İnsan Bilimleri Dergisi. 2004;1:1-8.

6. Akçakın M, Erden G. Otizm tanısı konmuş çocukların anne babalarındaki ruhsal belirtiler, Çocuk Ruh Sağllğ̆ Dergisi. 2001;8:2-10.

7. Köroğlu E. Psikiyatri Temel Kitabı. Ankara, Hekimler Birlĭgi Yayınevi, 2007.

8. Gerald DC, Neale MJ. Anormal Psikoloji (Çev. Ed. İ Dağ). Ankara, Türk Psikologlar Derneği Yayınları, 2004.

9. Şener EF, Özkul Y. Otizmin genetik temelleri. Sağlık Bilimleri Dergisi. 2013;22:86-92.

10. Sarısoy M. Otistik ve zihinsel engelli çocuğa sahip ebeveynlerin evlilik uyumları (Yüksek lisans tezi). İzmir, Ege Üniversitesi, 2000.

11. Norton P, Drew, C. Autism and potential family stressors. Am J Fam Ther. 1994;22:67-76.

12. Uljarević M, Carrington S, Leekam S. Brief report: Effects of sensory sensitivity and intolerance of uncertainty on anxiety in mothers of children with autism spectrum disorder. J Autism Dev Disord. 2016;46:315-9.

13. Zeteroğlu EŞ. Yirmi beş-yetmiş iki aylar arasındaki otistik çocukların gelişimlerinin incelenmesi (Yüksek lisans tezi). Ankara, Gazi Üniversitesi, 2006.

14. Baykara B. Otistik çocukların anne babalarında geniş otizm fenotipinin nörobilişsel görünümünün 
araştırılması (Uzmanlık tezi). İzmir, Dokuz Eylül Üniversitesi, 2003.

15. Machado Junior SB, Celestino MIO, Serra JPC, Caron J, Pondé MP. Risk and protective factors for symptoms of anxiety and depression in parents of children with autism spectrum disorder. Dev Neurorehabil. 2016;19:146-53.

16. Wang J, Hu Y, Wang Y, Qin X, Xia W, Sun C et al. Parenting stress in Chinese mothers of children with autism spectrum disorders. Soc Psychiatry Psychiatr Epidemiol. 2013;48:575-82.

17. Gündoğdu FB. Otistik ve normal çocuğu olan anababaların evlilik uyumlarını algilamaları ve bazı değişkenler bakımından karşılaştırılması (Yüksek lisans tezi). Ankara, Ankara Üniversitesi, 1995.

18. Firat S, Diler RS, Avci A, Seydaoglu G. Comparison of psychopathology in the mothers of autistic and mentally retarded children. J Korean Med Sci. 2002;17:679-85.

19. Öner N, Le Compte A. Manual of Unsteady State/Trait Anxiety Inventory. İstanbul, Boğaziçi Üniversitesi Yayınevi, 1998.

20. Hisli N. Beck depresyon envanterinin üniversite öğrencileri için geçerliği, güvenirliği. Psikoloji Dergisi. 1989;7:3-13.

21. Aydemir Ö, Köroğlu E. Psikiyatride Kullanılan Klinik Ölçekler. Ankara, Hekimler Yayın Birliği, 2000.

22. Benedict RHB, Fishman I, McClellan MM, Bakshi R, Weinstock-Guttman B. Validity of the Beck depression inventory-fast screen in multiple sclerosis. Mult. Scler. 2003;9:393-6.

23. McManus V, Michelsen SI, Parkinson K, Colver A, Beckung E, Pez $\mathrm{O}$ et al. Discussion groups with parents of children with cerebral palsy in Europe designed to asist development of a relevant measure of environment. Child Care Health Dev. 2006;32:185-92.
24. Al-Kuwari MG. Psychological health of mothers caring for mentally disabled children in Qatar. Neurosciences. 2007;12:312-7.

25. Coşkun Y, Akkaş G. Engelli çocuğu olan annelerin sürekli kayg1 düzeyleri ile sosyal destek algıları arasındaki ilişki. KEFAD. 2009;10:213-27.

26. Dereli F, Okur S. Engelli çocuğa sahip olan ailelerin depresyon durumunun belirlenmesi. Yeni Tip Dergisi. 2008;25:164-8.

27. Tsai SM, Wang HH. The relationship between caregiver's strain and social supprt among mothers with intellectually disabled children. J Clin Nurs. 2009;18:539-48.

28. Uyaroğlu AK, Bodur S. Zihinsel yetersizliği olan çocukların anne-babaların kayg1 düzeyi ve bilgilendirmenin kayg1 düzeyine etkisi. TSK Koruyucu Hekimlik Bülteni. 2009;8:405-12.

29. Hastings RP, Brown T. Behavior problems of children with autism, parental self-efficacy, and mental health. Am J Ment Retard. 2002;107:222-32.

30. Weiss MJ. Hardiness and social support as predictors of stress in mothers of typical children, children with autism, and children with mental retardation. Autism. 2002;6:115-30.

31. Shu BC, Lung FW, Chang YY. The mental health in mothers with autistic children: A case-control study in Southern Taiwan. Kaohsiung J Med Sci. 2000;16:308-14.

32. Singer GH, Irvin LK, Hawkins N. Stress management training for parents of children with severe handicaps. Ment Retard. 1988;26:269-77.

33. Baykoç DN, Bayhan P, Artan İ. Engelli çocuğa sahip ailelerin beklentileri ve endişe duydukları konuların incelenmesi. Sosyal Hizmetler Dergisi. 2000;1:16-23.

34. Heller T, Hsieh K, Rowitz L. Maternal and paternal caregiving of persons with mental retardation across the lifespan. Fam Relat. 1997;46:407-15. 